\title{
Position of Judicial OfFicers in the CZECH REPUBLIC IN COMPARISON With OTHER EUROPEAN COUNTRIES
}

\author{
Petra Juřátková \\ Faculty of Law, Palacký University Olomouc, Czech Republic \\ pe.konecna@gmail.com
}

JUŘÁTKOVÁ, Petra. Position of Judicial Officers in the Czech Republic in Comparison with other European Countries. International and Comparative Law Review, 2017, vol. 17, no. 1, pp. 223-237. DOI 10.2478/iclr-2018-0010.

\begin{abstract}
Summary: Main topic of this article is the comparison of the position of a judicial officer in the Czech Republic and in other European countries. First, it briefly presents the reasons why the institution of judicial officers has been (re)introduced to the Czech legal order. Further, it sums up the conception of the position of judicial officer in the Czech legal order, and with respect to actual critical reviews, it compares selected aspects of the conception of judicial officers in other European countries, with a special attention to so-called secondary activities of judicial officers and the issue of remuneration of judicial officers.
\end{abstract}

Keywords: judicial officer, court execution, Enforcement Code, Code of Civil Procedure

\section{Introduction}

The institution of judicial officers is considered a traditional element of enforcement of law. It existed within the territory of the Czech Republic before the World War II, though not continually, as it is e.g. in France, Belgium, the Netherlands, or Luxembourg. ${ }^{1}$ However, the then position of judicial officers was completely different from the current one. The reintroduction of the institute of judicial officers into the Czech legal order came on 1 May 2001, when Act No. 120/2001 Sb., on Judicial Officers and Enforcement (Enforcement Code) as amended (hereinafter "Enforcement Code" or "EC") came to effect. Since then there is so-called double-track system in the enforcement procedure (in a wider sense), or dualism, which means that the person empowered with the Enforcement Order may choose (with certain exceptions ${ }^{2}$ ) whether the claim, recognised by this Enforcement Order, shall be enforced within execution of court decision under Act No. 99/1963 Sb., Code of Civil Procedure, as amended (hereinafter

1 Territorial jurisdiction of judicial officers applies throughout the whole European Union [online]. Platforma za teritorialitu soudních exekutorů, 19. 11. 2014 [quoted on 31. 1. 2016]. Available at $<$ http://teritorialita.webnode.cz/news/mistni-prislusnost-soudnichexekutoru-funguje-v-cele-evropske-unii/>.

2 Cf. $\$ 251$ par 1 CCP as amended effective from 1 July 2015 and $\$ 37$ par 2 letter b) EC.

Published by Palacký University Olomouc, Czech Republic, 2017.

ISSN (print): 1213-8770; ISSN (online): 2464-6601 
"Code of Civil Procedure" or "CCP"), or within enforcement procedure pursuant to the Enforcement Code. At present, the institution of judicial officers has been facing a strong wave of criticism. Still more spoken is not only the limitation or temporary ban of the double-track system, but also dismissal of enforcement under Enforcement Code as a way of enforcement of claims. For the author, this situation was the impulse to present some thoughts on the prospects of judicial officers as well as to map the conditions in other European countries. First, the article briefly gives the reasons why the institute of judicial officers has been (re)introduced to the Czech legal order. Further, it sums up the conception of the position of judicial officers in the Czech legal order and with respect to the current critical reviews the article compares selected aspects of the position of Czech judicial officers with that in other countries of the European Union. In more detail it focuses at so-called secondary activities of judicial officers and the issue of remuneration. The author would like to announce that defence of judicial officers is definitely not the objective of the article.

\section{Reasons for introduction of the institution of judicial officers in the Czech Republic}

In respect to the criticism of the current conception of court executions there arises a question for what reason the conception was chosen in the Czech legal environment. The implementation of the institution of judicial officials was not the only option, then. Also considered was for example an extended amendment to the rather outdated legal regulation on enforcement of judgements, which, in the author's opinion, would not suffice as such. Furthermore, such an amendment would have considerably burdened the state budget and the functioning of the judiciary, which was probably apparent to the legislators as well. Despite the fact that the last (also the planned) amendments rather lead to a gradual limitation of activities of judicial officers, they expand applicability of executions (pursuant to Enforcement Code) to the detriment of enforcement of the judgement.

The primary motive ${ }^{3}$ to introduce judicial officers was a low efficiency of enforcement through enforcement of judgement, which allegedly varied from about $1 \%$ to $5 \%$ (detailed analysis is not available, though) 4 . In countries where recovery of claims is performed by private enforcement agents, the success rate then was (allegedly) two-third. It was presumed that the introduction of the institution of judicial officers would make a $70 \%$ increase in efficiency of enforcement of claims. ${ }^{5}$ However, statistics published by the Chamber of

3 Document of the Chamber 725/0. Draft Bill on Judicial Officers [online]. House of Representatives of the Parliament of the Czech Republic [quoted on 29. 1. 2017]. Available at $<$ http://www.psp.cz/sqw/text/tiskt.sqw?o $=3 \& \mathrm{ct}=725 \& \mathrm{ct} 1=0>$.

4 Závěrečná analýza systémových chyb na poli exekucí [online]. Iuridicum Remedium, o. s., 2012 [quoted on 29. 1.2017]. Available at <http://www.osf.cz/wp-content/uploads/2015/08/ IuRe_Zaverecna_analyza_systemovych_chyb_na_polic_exekuci_cervenec_2012.pdf > .

5 Bill proposal by MP's Pavel Němec, Pavel Svoboda, Cyril Svoboda, Zdeněk Koudelka, 
Judicial Officers of the Czech Republic show that the number of executions that succeed in complete exacting the debt including accessions make only about $30 \%$ and it has rather decreasing tendency. Despite the total number of executions has been decreasing (in the last two years the number of physical persons undergoing execution went down by $27 \%),{ }^{6}$ there is an increasing number of debtors with two or more executions. ${ }^{7}$ Probability of successful exaction of the claim including accessions is minimal as concerns multiple executions. According to the "Analysis of execution environment with an accent on dislocation of Executor's Offices and expensiveness of executions" presented by the Ministry of Justice of the Czech Republic (hereinafter "Analysis") the largest number of execution proceedings $(54,46 \%$ ) are those proceedings in which the debtor does not dispose with any property that could be used for execution, or the amount of the property in not sufficient for successful exaction of the claim at least within five years from commencement of the execution proceeding. ${ }^{8}$ Another motive was to reduce the workload of courts.

\section{Position of judicial officer}

\subsection{On the position of judicial officer in the Czech Republic}

Judicial officers are appointed for performance of the executor's office, the seat of which is by rule the municipality that hosts the District Court within jurisdiction of which the judicial officer has been appointed. The officers are delegated with the part of the court's powers that are exercised after issuance of the Enforcement Order'. Despite that, the officers do not hold identical position with judges

Eva Dundáčková and others of Act on Judicial Officers and Executive Activities (Enforcement Code) and on amendment and supplementation of other acts / parliamentary document 725/ - second reading [online]. House of Representatives of the Parliament of the Czech Republic, 24. 1. 2001 [quoted on 29. 1. 2017]. Available at <http://www.psp.cz/ eknih/1998ps/stenprot/032schuz/s032049.htm\#r8>.

6 Descending trend in the number of executions is essentially a positive phenomenon, though it does not guarantee increased solvency of the debtors. The number of executions decreased for many reasons, one of them being the introduction of so-called merging of execution proceedings under Amendment to Act No. 396/2012 Sb. At the analysis and assessment of impacts of decrease in the number of executions it is necessary to take into consideration all relevant factors including succession with insolvency proceedings.

7 SAHULA, David. Dramaticky roste počet dlužníkủ s více exekucemi. Čtyři a více exekucí již má 380 tisíc lidí [online]. Právní prostor, 8. 10. 2015 [quoted on 29. 1. 2017]. Available at $<$ http://www.pravniprostor.cz/aktuality/aktuality/dramaticky-roste-pocet-dluzniku-svice-exekucemi-ctyri-a-vice-exekuci-jiz-ma-380-tisic-lidi>.

8 Závěrečná analýza systémových chyb na poli exekucí. [online]. Iuridicum Remedium, o. s., 2012 [quoted on 29. 1. 2017]. Available at <http://www.osf.cz/wp-content/ uploads/2015/08/IuRe_Zaverecna_analyza_systemovych_chyb_na_polic_exekuci_cervenec_2012.pdf>.

9 Parliamentary document 725/0. Draft Bill on Judicial Officers [online]. House of Representatives of the Parliament of the Czech Republic [quoted on 29. 1. 2017]. Available at $<$ http://www.psp.cz/sqw/text/tiskt.sqw?o=3\&ct=725\&ct1 $=0>$. 
(even though their acts are considered acts of the Executions Court under $₫ 28$ Execution Code). Upon performance of executory activities the judicial officer acts as a public official. On the other hand, for example in court decision-making on costs of the proceeding the officer acts as a party of the proceeding who is financially interested in the result of the execution, since s/he is a self-employed person (sui generis). ${ }^{10}$ The Constitutional Court even classifies judicial officer as an entrepreneur whose essential feature is "a permanent activity carried out for the purpose of producing a profit and at his own risk as concerns relationship with the entitled person". ${ }^{11}$ Unlike advocates, judicial officers are not allowed, except executory and other activities carried out for a consideration, to perform activities other than scientific, publishing, pedagogic, interpreting, expert, artistic, and activities performed at advisory bodies of the government, ministries or other bodies of state or local administration ( $\$ 3$ par. 2 EC). Although the function of judicial officer is carried out for a consideration ( $\$ 3$ par. $1 \mathrm{EC}$ ), salary is not guaranteed since it depends on the effectiveness of exacting thereof. Judicial officers unite in a professional body, which is the Chamber of Judicial Officers of the Czech Republic.

\subsection{Foreign regulations of the institution of judicial officers}

The institution of judicial officers is not unknown to other European countries. Probably the most significant representative of this conception is France. In France in 1949 emerged the idea to establish the "Union International of Judicial Officers" ("UIHJ" in short) which came to existence in 1952. Its first members were Belgium, France, Greece, Italy, Luxembourg, the Netherlands, and Switzerland. At present the UIHJ operates throughout the world, the Czech Republic being its rather significant member. ${ }^{12}$ The French legal regulation is not mentioned randomly. As will be clear from the following, legal regulation contained in the Enforcement Code resembles the French arrangement in many respects, and that it why it has been chosen as a source of legal regulation for the comparison.

French judicial officers are, similarly to the Czech ones, persons in authority, appointed by the Minister of Justice. They are entitled to perform their profes-

10 Opinion of the Constitutional Court of 12. 9. 2006, ref. No. Pl. ÚS - st. 23/06.

11 Judgment of the Constitutional Court of 31. 8. 2004, ref. No. II. ÚS 150/04.

12 Rather significant, as the former President of the Chamber of Judicial Officers and at the same time a Court Officer appointed with leadership of the Executor's Office Praha 5 in 2012 through 2015, operate as a UIHJ Secretary, where he was in charge of agenda for the Central and Eastern Europe, namely financial issues, in 2015 we re-elected to the UIHJ Committee for a three-year term (Podkonický zvolen do Výboru Mezinárodní unie soudních exekutorů [online]. vz24.cz, 10. 5. 2012 [quoted on 29. 1. 2017]. Available at <http:// www.vz24.cz/clanky/podkonicky-zvolen-do-vyboru-mezinarodni-unie-soudnich-exekutoru/>; A Woman at the Head of the International Union of Judicial Officers [online]. uihj, 5. 6. 2015 [quoted on 29. 1. 2017]. Available at <http://www.uihj.com/en/a-woman-at-thehead-of-the-international-union-of-judicial-officers_2164395.html>). 
sion, consisting among others in enforcement of court decisions and other executory titles, including executor's records that they are also entitled to draw up, as a liberal profession, since the year 1923. Unlike their Czech colleagues, they do not have to operate individually, they may get associated into some form of capital companies. This option exists also for example in Luxembourg, Belgium, or the Netherlands. ${ }^{13}$

Their number is limited (numerus clausus), alike in the Czech Republic. For the record, in the Czech Republic currently operate 154 judicial officers. In the future, however, we may anticipate a decrease, considering the current events, ${ }^{14}$ which is supported also by the fact that newly vacant offices repeatedly fail to get filled. On the other hand, in Slovakia in 2015 operated 305 judicial officers. ${ }^{15}$ In Belgium the same year it was 556 judicial officers ${ }^{16}$, in the Netherlands $385^{17}$, in Hungary $219^{18}$, in France surprisingly $3,200^{19}$, out of which 700 simultaneously perform the activities of administrators of immovable property ${ }^{20}$, and in Germany it was $4,620^{21}$. Position of German judicial officers is rather different since they do not perform their activities as private entities but as state servants. It is therefore evident at the first sight that the number of Czech judicial officers is considerably lower in comparison with some other countries. ${ }^{22}$ The current indirect effort of legislators to further reduce the number of judicial officers therefore seems rather paradoxical.

In France judicial officers operate territorially, within jurisdiction of the appellative court they belong to (in the past they operated only within the region

13 ŠEDIVÝ, Jiří. Čeští exekutoři nikterak nevyčnívají [online]. Peníze.cz [quoted on 29. 1. 2017]. Available at <http://www.penize.cz/17493-cesti-exekutori-nikterak-nevycnivaji $>$.

14 Odchody exekutorů pokračují, minulý týden rezignoval již 11 . exekutor v tomto roce [online]. Ekcr.cz [quoted on 29. 1. 2017]. Available at $<$ http://ekcr.cz/1/aktuality-promedia/2208-odchody-exekutoru-pokracuji-minuly-tyden-rezignoval-jiz-11-exekutor-vtomto-roce? $\mathrm{w}=>$

15 The Judicial Officer in the World - Slovakia [online]. Uihj.cz, 10.11.2015 [quoted on 29. 1. 2017]. Available at $<$ http://www.uihj.com/en/ressources/10148/78/slovakia_-_en.pdf $>$.

16 The Judicial Officer in the World - Belgium [online]. Uihj.cz, 10. 11.2015 [quoted on 29. 1. 2017]. Available at <http://www.uihj.com/en/ressources/21650/87/belgium_-_en.pdf $>$.

17 The Judicial Officer in the World - Netherlands [online]. Uihj.cz, 10. 11.2015 [quoted on 29. 1. 2017]. Available at $<$ http://www.uihj.com/en/ressources/10148/86/netherlands_-en.pdf>.

18 The Judicial Officer in the World - Hungary [online]. Uihj.cz, 10. 11.2015 [quoted on 29. 1. 2017]. Available at <http://www.uihj.com/en/ressources/10148/50/hungary_-_en.pdf >.

19 The Judicial Officer in the World - France [online]. Uihj.cz, 10. 11.2015 [quoted on 29. 1. 2017]. Available at <http://www.uihj.com/en/ressources/10148/54/france_-_en.pdf>.

20 CHARDON, Mathieu. CEPEJ Directive in the French law. Komorní listy, 2016, vol. 8, No. 4, p. 36-38.

21 The Judicial Officer in the World - Germany [online]. Uihj.cz, 10. 11.2015 [quoted on 29. 1. 2017]. Available at <http://www.uihj.com/en/ressources/21650/84/germany_-_en.pdf $>$.

22 When we compare the number of judicial officers and population in the respective country. 
of the court of $1^{\text {st }}$ instance). After all, territoriality (see the Chart herein below) has been implemented in most European countries except the Czech Republic, Albania, the Netherlands and Slovakia, where at present was submitted amendment to Act No. 233/1995 Z. z., on judicial officers and executory activities (Rules of execution) and on amendment and supplement of other acts, which envisages implementation of territoriality on the level of regional (appellate) court (similar to France). ${ }^{23}$ The tendency to withdraw from territoriality is also apparent (e.g. in Portugal, Estonia, Germany or France $)^{24}$ since it has been proved that competitive environment is desirable for judicial officers as persons pursuing a liberal profession. This argument is often used by the Czech opponents of territoriality. ${ }^{25}$ That is, introduction of territoriality has long been considered also in the Czech environment. ${ }^{26}$

\subsubsection{Secondary activities and remuneration of judicial officers}

Already the Guidelines for a Better Implementation of the Existing Council of Europe's Recommendation on Enforcement of 17. 12. 2009; CEPEJ (2009)11REV2, adopted by the CEPEJ ${ }^{27}$ Commission on its $14^{\text {th }}$ plenary meeting (Strasbourg 9-10 December 2009) in article 34 envisages that „enforcement agents may also be authorized to perform secondary activities compatible with their role, tending to safeguard and secure recognition of parties' rights and aimed at expediting the judicial process or reducing the workload of the courts. These may be, among others debt recovery; voluntary sale of moveable or immoveable prop-

23 PALLER, Miroslav. 20. výročie existencie slovenskej komory exekútorov. Komorní listy, 2016, vol. 8, No. 4, p.. 76-78.

$24(\mathrm{Ne})$ zavedení teritoriality v České republice [online]. Komorní noviny, 20. 10. 2015 [quoted on 29. 1. 2017]. Available at <http://www.kn.cz/clanek/nezavedeni-teritoriality-v-ceskerepublice>; Novela zlikviduje konkurenci mezi soudními exekutory a sníží vymahatelnost pohledávek [online]. Státní správa, 2. 7. 2015 [quoted on 29. 1. 2017]. Available at <http:// www.statnisprava.cz/rstsp/clanky.nsf/i/novela_zlikviduje_konkurenci_mezi_soudnimi_ exekutory_a_snizi_vymahatelnost_pohledavek_15070111_98702983>.

25 Novela zlikviduje konkurenci mezi soudními exekutory a sníží vymahatelnost pohledávek [online]. Státní správa, 2. 7. 2015 [quoted on 29. 1. 2017]. Available at $<$ http://www.statnisprava.cz/rstsp/clanky.nsf/i/novela_zlikviduje_konkurenci_mezi_soudnimi_exekutory_a_ snizi_vymahatelnost_pohledavek_15070111_98702983>.

26 Místní př́slušnost soudních exekutorů funguje v celé Evropské unii [online]. Platforma za teritorialitu soudních exekutorů, 19. 11. 2014 [quoted on 29. 1. 2017]. Available at <http:// teritorialita.webnode.cz/news/mistni-prislusnost-soudnich-exekutoru-funguje-v-celeevropske-unii/>.

27 CEPEJ means The European Commission for the Efficiency of Justice. The CEPEJ is made up of representatives of the 47 member states of the Council of Europe. Its aim is the improvement of the efficiency and functioning of justice in the member States, and the development of the implementation of the instruments adopted by the Council of Europe - See What are the objectives of the CEPEJ? [online]. Council of Europe [quoted on 29. 1. 2017]. Available at <http://www.coe.int/t/dghl/cooperation/cepej/presentation/CEPEJ_ depliant_en.pdf $>$; About the CEPEJ... [online]. Council of Europe [quoted on 29. 1. 2017]. Available at $<$ http://www.coe.int/t/dghl/cooperation/cepej/presentation/cepej_en.asp > . 
erty at public auction; seizure of goods; recording and reporting of evidence; serving as court ushers; provision of legal advice; bankruptcy procedures; performing tasks assigned to them by the courts; representing parties in the courts; drawing up private deeds and documents; teaching " ${ }^{28}$ French judicial officers are entitled, in addition to enforcement of claims, to perform a variety of other secondary activities, including conciliatory recovery of debts, voluntary sales of movables at auction, recording of evidence, performance of activities of court executors, provision of legal advice, entering into insolvency proceedings, investigation for verification of facts for court proceedings (for example, presence at the meeting of co-owners, actual works done or checking accuracy of accountancy), representing parties at court, drawing up private deeds and participation in vocational training, and also for example drawing up an Enforcement Order in the case of failure to cash a check, mediation, registration of mortgages, checking of accounts in connection with performance of guardianship and preliminary measures within probate proceedings, etc. ${ }^{29}$ In England and Wales judicial officers (among others) perform exaction of financial penalties imposed within criminal proceeding, and if the payment fails, the officers will ensure subsequent detention and bringing the respective persons before the court. ${ }^{30}$ In the Netherlands, secondary activities make about $40 \%$ of the judicial officer's work, which is hard to imagine in the Czech environment since the range of secondary (or other additional) activities is not very large. The judicial officer is authorised, among others, to provide legal assistance for the entitled or obligated person after issuance of Enforcement Order as well as in relation to executor's activities and other additional activities, to perform authorised conversion of documents, to receive money, documents, deeds and other movable things for safekeeping, to deliver documents, etc. (cf. $\$ 74$ et al. EC). In fact, these are activities that do not form the basis (in economic sense) for functioning of the executor's office. Different situation existed here till 31 December 2012, when the Enforcement Code permitted for judicial officers to draw up, within so-called secondary activities, executor's records with an order for direct enforcement, which was often exploited by small executor's offices that got specialized in drawing up the records. Effective from 1 January 2013, judicial officer is only authorised to draw up the executor's records that prove the facts or circumstances of the case. The

28 NETTEN, Leo. About the CEPEJ. Komorní listy, 2016, vol. 8, No. 4, p. 31-32; CEPEJ(2009)11REV2 - Guidelines for a better implementation of the existing council of Europe's recommendation on enforcement adopted by the CEPEJ at its 14th plenary meeting (Strasbourg, 9-10 December 2009) [online]. Council of Europe [quoted on 29. 1. 2017]. Available at $<$ https://wcd.coe.int/ViewDoc.jsp? $\mathrm{p}=\& \mathrm{id}=1565277 \&$ Site $=\&$ BackColor Internet $=$ B9BDEE\&BackColorIntranet $=$ FFCD4F \&BackColorLogged $=$ FFC679\&direct $=\operatorname{tr}$ ue. $\&$ direct $=$ true $>$.

29 HOZMAN, David. Konference k 15. výročí Exekutorské komory ČR. Komorní listy, 2016, vol. 8, No. 4, p. 18-21; CHARDON, Mathieu. Směrnice CEPEJ ve francouzském právu. Komorní listy, 2016, vol. 8, No. 4, p. 36-38.

30 LEYSHON, Martin. Mimoexekuční činnost soudních exekutorů v Anglii a Walesu. Komorní listy, 2016, vol. 8, No. 4, p. 57-58. 
revocation for judicial officers of the option to draw up executor's records with the approval of direct enforcement was reasoned among others by the opinion that the judicial officer should primarily concentrate on forced enforcement of decisions. Drawing up official documents (executor's record with approval of direct enforcement is an official document) should be concentrated in the hands of notaries. This arrangement allegedly corresponds with the essential division of particular activities in law among existing legal professions. ${ }^{31}$ However, the author does not consider such reasoning sufficient. After all, executor's record attesting facts or circumstances of the case is an official document and the power to draw up the records has not been removed from judicial officers. Executor's record with the approval of enforcement has only a formal character and does not have substantive nature. ${ }^{32}$. The settlement between the entitled and obligated person contained within is merely one of the formalities the executor's record with the approval of direct enforcement must contain in order to be executable from material viewpoint; this settlement as such does not result in establishment, alternation or termination of rights or liabilities of participants of the legal relationship (therefore it cannot be a composition or novation). Despite it is (was) a title to order an execution, it is not a decision, independent binding reason, it does not establish presumption of existence of a debt in the moment of the drawing up and does not establish an obstacle that could prevent the dispute for identical performance from hearing before the court. ${ }^{33}$ Therefore, it does not prevent any contractual party to address the court as concerns the given case. The fact that the contractual parties have not done so and have chosen the form of executor's record should not be put to the detriment of the judicial officer, who, regardless his drawing up the Enforcement Order which $\mathrm{s} / \mathrm{he}$ is him/herself subsequently entitled to enforce, is obliged to proceed independently and impartially ( $\$ 2 \mathrm{EC}$ ). ${ }^{34}$ Notwithstanding the fact that the producing of Enforcement Orders directly by judicial officers may contribute to the reduction of the workload of the courts, especially as concerns "simple" cases in which the parties are willing and able to come to an agreement. The option to produce Enforcement Orders is, among others, permitted for example in Serbia, Georgia or Ukraine. ${ }^{35}$ In France the judicial officers may issue Enforcement Orders relating to claims up to EUR 4,000 in accelerated (shortened) proceedings, which however requires

31 Explanatory note to Act No. 396/2012 Sb. [online]. House of Representatives of the Parliament of the Czech Republic [quoted on 29. 1. 2017]. Available at <http://www.psp.cz/sqw/ text/orig2.sqw?idd $=76211 \& \mathrm{pdf}=1>$.

32 Judgement of the Supreme Court of 25. 8. 2004, ref. No. 20 Cdo 1232/2004.

33 Judgement of the Supreme Court of 14. 10. 2016, ref No. 20 Cdo 3953/2016, and herein quoted judgements.

34 Cf. Opinion of the Civil Law and Commercial Collegium of the Supreme Court of 15. 2. 2006, Cpjn 200/2005, published under No. 31/2006 Collection of Court Decisions and Opinions, or Judgement of the Constitutional Court of 27. 11. 2007 ref. No. II. ÚS 1331/07.

35 UITDEHAAG, Jop. Budoucnost soudního exekutora. . Komorní listy, 2016, vol. 8, No. 4, p. 43-46; HOZMAN, David. Konference k 15. výročí Exekutorské komory ČR. Komorní listy, 2016, vol. 8, No. 4, p. 18-21. 
"cooperation" of the debtor (analogous to the Czech Order for Payment Procedure, cf. 172 et al. Code of Civil Proceedings). The judicial officer who has issued the enforcement order in accelerated proceeding may not subsequently exact it, which can be viewed as a compromise between the conditions that were in the Czech Republic until 31 December 2012 and the situation after 1 January 2013.

As apparent from the above said, in France, alike in other European countries, the executory activities are not the only source of livelihood of private judicial officers. For their performance in respect of executions (not for so-called secondary activities, as is e.g. legal assistance etc., or in the case of conciliatory settlement of the execution, when the officer's fee is contractual) the officers are entitled to tariff remuneration, set by a regulation and proportional to the exacted debt. As a rule, the execution costs are paid by the obligated person. ${ }^{36}$ In the Czech Republic, remuneration for execution that implies payment an amount of money makes $15 \%$ of the exacted performance (up to CZK 3,000,000), not including the costs of the execution and costs of the entitled person, at least CZK $3,000 .{ }^{37}$ For example, in Slovakia the remuneration of the executor is always 20 $\%$ of the exacted performance (without upper limitation), at least EUR 33.19 and maximum EUR 33,193.92. For the reason of absent upper limitation of the exacted performance, the remuneration in Slovakia is much higher than that one of Czech judicial officers. ${ }^{38}$ In this context is often mentioned the German regulation that is often, though inappropriately, presented as a model for the Czech regulation. Inappropriately - because at executions the institution of strictly private enforcement officers does not exist. In Germany instead of judicial officer there is a court enforcement official (Gerichtsvollzieher), who performs his function in service of the respective Federal State. Salary of the court enforcement official is paid form the budget of respective Federal State as well as other variable components in the form of premiums and incentives from the exacted performance, out of which the court enforcement officials cover the operation of their offices. ${ }^{39}$ At least in this respect, the position of German court enforcement officials partly resembles the Czech regulation. However, unlike Czech judicial officers, in Germany they are paid with fixed salary. Activities of German Gerichtsvollziehers resemble executions of court decisions rather than executions under the Execution Code.

36 In the case of destitution of the obligated person $₫ 89$ EC applies analogically.

37 Cf. $\$ 5$ par. 1 and 6 Regulation of the Ministry of Justice No. 330/2001 Sb., on Remuneration and Compensation for Judicial Officers, on Remuneration and Compensation for Cash Expenses of Managers, and on Terms of Insurance of Liability for Damage Caused by Judicial Officer.

38 Regulations of the Ministry of Justice of the Slovak Republic No. 288/1995 Coll., on Remuneration and Compensations for Judicial Officers.

39 BÁČOVÁ, Petra. Germany lacks judicial officers, courts annually commence more than 6 million enforcements of decision [online]. Ekcr.cz, 18. 11. 2013 [quoted on 29. 1. 2017]. Available at $<$ http://ekcr.cz/1/aktuality-pro-media/1403-v-nemecku-exekutory-nemajitamni-soudy-rocne-zahaji-vice-nez-6-milionu-vykonu-rozhodnuti-18-11-2013?w=>. 
In the Czech legal environment we are currently talking about the need to reduce the costs of a judicial officer. However, it is important to realize that the judicial officer is a liberal profession "sui generis". Its position should not be confused with the "normal" entrepreneur, as it does the Constitutional Court, even with a position of advocates. ${ }^{40}$ Judicial officers are not allowed, except executory and other activities carried out for a consideration, to perform other activities than scientific, publishing, pedagogic, interpreting, expert, artistic, and activities performed at advisory bodies of the government, ministries or other bodies of state or local administration ( $\$ 3$ par. $2 \mathrm{EC}$ ). They cannot, for example (such as advocates) to act as insolvency administrators. This option allows, for example, the Estonian legislation, where the judicial officer can act as a bankruptcy trustee. If a debtor has declared bankruptcy, the judicial officer may ask the court to appoint him or her to the position of a bankruptcy trustee. If a debtor has declared bankruptcy, probability that a judicial officer will be reimbursed the costs of enforcement, is significantly reduced. ${ }^{41}$ The above procedure is the form of compensation for the inability to satisfy the costs of enforcement if the debtor falls into bankruptcy in the course of enforcement. ${ }^{42}$ Consistency between enforcement and insolvency proceedings is also evident in other countries. For example, in France, the judicial officer may, from 1st January 2017 intervene in bankruptcy procedures of when these procedures are initiated against debtors having no employees and who achieve a turnover lower or equal to EUR $100,000 .{ }^{43}$ In England and Wales are the chosen judicial officers authorized to prepare an insolvency petition (as well as other legal documents). This option was also considered in our country - so far unsuccessfully. While it is true that the purpose of enforcement proceedings is different than the purpose of insolvency proceedings. The point of insolvency proceedings consists of bulk property settlement of the debt (in the form of rehabilitation or liquidation). In insolvency proceedings, therefore, is not merely to satisfy a creditor's claim against the debtor, but satisfy claims (preferably and ideally) of all creditors of the debtor. These two proceedings should therefore not be confused, however, there is no reason to have overlooked some parallels. Insolvency proceedings often follows (mingle) with the enforcement, which mainly enforcement proceedings fundamentally affects negatively. The author believes that existing legislation does not establish "privileged status" of claims of judicial officers, on the other hand,

40 Judgment of the Constitutional Court of 2. 3. 2006, ref. No. II. ÚS 9/06.

41 This problem is also known in the Czech legislation - cf. Constitutional Court judgment of 6. 9. 2016, Ref. No. IV. US 378/16, a Supreme Court judgement of 23. 10. 2014, Ref. No. 21 Cdo 3182/2014, published under No. 32/2015 Collections judgments and opinions.

42 HOZMAN, David. Konference k 15. výročí Exekutorské komory ČR. Komorní listy, 2016, vol. 8, No. 4, p. 18-21.

43 CHARDON, Mathieu. CEPEJ Directive in the French law. Komorní listy, 2016, vol. 8, No. 4, p. 36-38. 
however, does not preclude the judicial officer held in relation to the insolvency proceedings more prominent role. ${ }^{44}$

According to the $\$ 74$ par. 1 EC the judicial officer is among other things authorized to provide legal assistance to the creditor or debtor after an enforcement order was issued (irrelevant is when the enforcement order becomes enforceable), as well as in relation to the enforcement and other activities. Judicial officer, for example, can not represent the creditor in the enforcement proceedings, which performs. However, it is not excluded that the judicial officer first writes the execution proposal, and then asks for authorization to carry out the execution, which subsequently will be conducting. Providing legal advice in connection with the activities carried out by judicial officers is also well known in France and Estonia, where judicial officers have extensive powers. ${ }^{45}$

From the above it follows that judicial officers have limited options for further additional income. If the judicial officer finds that the exercise of his/her profession becomes an economically disadvantageous he or she has basically the only option which is to stop it. It is therefore important to maintain the economic independence of the judicial officers and to refuse unreasonable restrictions of enforcement. ${ }^{46}$ Of course this does not mean that judicial officers should not be untouchable. However, it is important to realize that the function enforcement (and insolvency) law is a prerequisite for the economic benefit of each state. ${ }^{47}$ It can be regarded as disproportionate those restrictions which disproportionately reduce costs (especially pay) of enforcement, which are not merely profit of judicial officers, but also the means to ensure the functioning of executor office. The level of remuneration should reflect, inter alia, higher intensity and complexity of enforcement activities and greater accountability of judicial officers. If the costs remain reduced without additional compensation, it could preclude further execution activities. At the current trend, which reduces the amount of foreclosures, declining effectiveness of recovery and increasing the number of multiple executions, it can be predicted that the decreasing profits will be for many judicial officers liquidation.

The above described situation and uncertainty over the payment of the costs of enforcement could solve (among other things) an effective system of backups (billable costs). The advance on the costs would be compulsorily paid by an authorized person at the time of the enforcement proposal (like for example

44 JUŘÁTKOVÁ, Petra. Uplatnění nákladů exekuce v insolvenčním řízení. Bulletin advokacie, roč. 2017, č. 1-2, s. 25-29.

45 CHARDON, Mathieu. CEPEJ Directive in the French law. Komorní listy, 2016, vol. 8, No. 4, p. 36-38.

46 FLAM, Jiří. Nezávislost soudního exekutora a jeho odměna. Komorní listy, 2016, vol. 8, No. 2, p. $15-19$.

47 SICKLINGER, Stephan. Das neue tschechische Insolvenzrecht aus der Sicht des deutschen Gläubigers. Sipplingen: JWV Jenaer Wissenschaftliche Verlagsgesellschaft mbH, 2009, p. 27. 
in Germany). ${ }^{48}$ The deposit is not to be confused with court fees (enforcement proposal is charged, for example, in Slovak Republic, England and Wales and in Austria, where it is understood, because executions are carried out by the state). System of backups is not unknown for enforcement proceeding, according to $₫$ 90 par. $3 \mathrm{EC}$ judicial officer has the right but not the obligation to request an advance on costs after creditors. In the event that the creditor refuses to lodge a deposit, a judicial officer is entitled to refuse to perform concrete action. [ $\$ 30$ point. b) EC], eventually the judicial officer may suspend enforcement proceedings at all ( $\$ 55$ par. $6 \mathrm{EC}$ ). The purpose of the advance on costs of enforcement should be to ensure sufficient funds for future operations of judicial officers in enforcement proceedings. Backups should address the situation when the debtor fails to pay costs of enforcement and judicial officer de facto works for free. In practice, backups are barely used. The reason is simple, for creditor is too risky to expend additional costs in situations where the likelihood of recovering the debt is not large. Obviously, this situation has two sides. If the creditor fails to pay the advance on costs, judicial officer runs the risk that no one pay the costs of enforcement in the case of the insolvency of the debtor. It is therefore necessary to re-locate evenly and fairly risk among creditors (beneficiaries) and judicial officers. The solution could eventually be to give creditors the possibility of tax relief as the form of compensation for the impossibility of recovering debts. Advances on the costs of enforcement should also be subject to exemptions (like works liberation of the court fee). Another option is to limit the time during which it is possible to recover the uncollectible amount. The executor or the court could stop the execution for the impregnability claims only if, for example, over the last 5 years of enforcement proceedings did not recover anything. A similar solution is proposed in Analysis. ${ }^{49}$

\section{Conclusion}

The aim of this paper was amongst other things to map the position Czech judicial officers and compare it with the status of judicial officers in other European countries, because at present, in the Czech Republic the institution of judicial officers has been facing a strong wave of criticism. This comparison showed that Czech legislation exhibits several similarities with foreign legislations. The actual powers of judicial officers - especially in the so-called secondary activities

48 SAHULA, David. Dramaticky roste počet dlužníků s více exekucemi. Čtyři a více exekucí již má 380 tisíc lidí [online]. Právní prostor, 8. 10. 2015 [quoted on 29. 1. 2017]. Available at <http://www.pravniprostor.cz/aktuality/aktuality/dramaticky-roste-pocet-dluzniku-svice-exekucemi-ctyri-a-vice-exekuci-jiz-ma-380-tisic-lidi>; Vymáhání pohledávek v Rakousku [online]. Business info, 18. 11. 2011 [cit. 29. 1. 2017]. Dostupné na <http://www. businessinfo.cz/cs/clanky/vymahani-pohledavek-v-rakousku-372.html>

49 Závěrečná analýza systémových chyb na poli exekucí [online]. Iuridicum Remedium, o. s., 2012 [quoted on

29. 1. 2017]. Available at <http://www.osf.cz/wp-content/uploads/2015/08/IuRe_Zaverecna_ analyza_systemovych_chyb_na_polic_exekuci_cervenec_2012.pdf > . 
- however, are considerably slashed. In the situation where the current legislative efforts is to reduce the costs of enforcement, in particular the remuneration of judicial officers, this state is unsustainable, and for a large part of judicial officers liquidation. Judicial officers are not untouchable. But - it is very important to realize that any further restriction of enforcement activities should be adequately compensated. This is the only way to guarantee the continuation of a functioning system of effective enforcement.

The Article is partly based on the author's contribution, which was presented at a conference called Olomouc's debates of young lawyers (2016), and it is the outcome of the project IGA_PF_2016_010.

\section{References (alphabetical order)}

A Woman at the Head of the International Union of Judicial Officers [online]. uihj, 5. 6. 2015 [quoted on 29. 1. 2017]. Available at $<$ http://www.uihj.com/en/a-woman-at-thehead-of-the-international-union-of-judicial-officers_2164395.html>.

About the CEPEJ... [online]. Council of Europe [quoted on 29. 1. 2017]. Available at $<\mathrm{http}: / /$ www.coe.int/t/dghl/cooperation/cepej/presentation/cepej_en.asp $>$.

BÁČOVÁ, Petra. Germany lacks judicial officers, courts annually commence more than 6 million enforcements of decision [online]. Ekcr.cz, 18. 11. 2013 [quoted on 29. 1. 2017]. Available at <http://ekcr.cz/1/aktuality-pro-media/1403-v-nemecku-exekutory-nemaji-tamni-soudy-rocne-zahaji-vice-nez-6-milionu-vykonu-rozhodnuti$18-11-2013$ ? $\mathrm{w}=>$.

Bill proposal by MP's Pavel Němec, Pavel Svoboda, Cyril Svoboda, Zdeněk Koudelka, Eva Dundáčková and others of Act on Judicial Officers and Executive Activities (Enforcement Code) and on amendment and supplementation of other acts / parliamentary document 725/ - second reading [online]. House of Representatives of the Parliament of the Czech Republic, 24. 1. 2001 [quoted on 29. 1. 2017]. Available at <http://www. psp.cz/eknih/1998ps/stenprot/032schuz/s032049.htm\#r8>.

CEPEJ means The European Commission for the Efficiency of Justice. The CEPEJ is made up of representatives of the 47 member states of the Council of Europe. Its aim is the improvement of the efficiency and functioning of justice in the member States, and the development of the implementation of the instruments adopted by the Council of Europe - See What are the objectives of the CEPEJ? [online]. Council of Europe [quoted on 29. 1. 2017]. Available at $<$ http://www.coe.int/t/dghl/cooperation/cepej/ presentation/CEPEJ_depliant_en.pdf $>$.

Constitutional Court judgment of 6. 9. 2016, Ref. No. IV. US 378/16.

Document of the Chamber 725/0. Draft Bill on Judicial Officers [online]. House of Representatives of the Parliament of the Czech Republic [quoted on 29. 1. 2017]. Available at $<$ http://www.psp.cz/sqw/text/tiskt.sqw? o $=3 \& c t=725 \& c t 1=0>$.

Explanatory note to Act No. 396/2012 Sb. [online]. House of Representatives of the Parliament of the Czech Republic [quoted on 29. 1.2017]. Available at <http://www.psp.cz/ sqw/text/orig2.sqw?idd $=76211 \& \mathrm{pdf}=1>$.

FLAM, Jiří. Nezávislost soudního exekutora a jeho odměna. Komorní listy, 2016, vol. 8, No. 2, p. 15-19.

HOZMAN, David. Konference k 15. výročí Exekutorské komory ČR. Komorní listy, 2016, vol. 8, No. 4, p. 18-21. 
CHARDON, Mathieu. CEPEJ Directive in the French law. Komorni listy, 2016, vol. 8, No. 4, p. 36-38.

Judgement of the Supreme Court of 25. 8. 2004, ref. No. 20 Cdo 1232/2004.

Judgment of the Constitutional Court of 31. 8. 2004, ref. No. II. ÚS 150/04.

Judgment of the Constitutional Court of 2. 3. 2006, ref. No. II. ÚS 9/06.

Judgement of the Constitutional Court of 27. 11. 2007 ref. No. II. ÚS 1331/07.

Judgement of the Supreme Court of 14. 10. 2016, ref No. 20 Cdo 3953/2016, and herein quoted judgements.

JUŘÁTKOVÁ, Petra. Uplatnění nákladů exekuce v insolvenčním řízení. Bulletin advokacie, roč. 2017, č. 1-2, s. 25-29.

LEYSHON, Martin. Mimoexekuční činnost soudních exekutorů v Anglii a Walesu. Komorní listy, 2016, vol. 8, No. 4, p. 57-58.

Místní př́slušnost soudních exekutorů funguje v celé Evropské unii [online]. Platforma za teritorialitu soudních exekutorů, 19. 11. 2014 [quoted on 29. 1. 2017]. Available at $\quad$ http://teritorialita.webnode.cz/news/mistni-prislusnost-soudnich-exekutorufunguje-v-cele-evropske-unii/>.

NETTEN, Leo. About the CEPEJ. Komorní listy, 2016, vol. 8, No. 4, p. 31-32; CEPEJ(2009)11REV2 - Guidelines for a better implementation of the existing council of Europe's recommendation on enforcement adopted by the CEPEJ at its 14th plenary meeting (Strasbourg, 9-10 December 2009) [online]. Council of Europe [quoted on 29. 1. 2017]. Available at $<$ https://wcd.coe.int/ViewDoc.jsp? $p=\& i d=1565277 \&$ Site $=\&$ BackColorInternet $=$ B9BDEE $\&$ BackColorIntranet $=$ FFCD4F $\&$ BackColorLogged $=$ FFC679\&direct $=$ true. $\&$ direct $=$ true $>$.

(Ne)zavedení teritoriality v České republice [online]. Komorní noviny, 20. 10. 2015 [quoted on 29. 1. 2017]. Available at $<\mathrm{http}$ ://www.kn.cz/clanek/nezavedeni-teritoriality-vceske-republice>.

Novela zlikviduje konkurenci mezi soudními exekutory a sníží vymahatelnost pohledávek [online]. Státní správa, 2. 7. 2015 [quoted on 29. 1. 2017]. Available at <http://www. statnisprava.cz/rstsp/clanky.nsf/i/novela_zlikviduje_konkurenci_mezi_soudnimi_ exekutory_a_snizi_vymahatelnost_pohledavek_15070111_98702983>.

Odchody exekutorů pokračují, minulý týden rezignoval již 11 . exekutor v tomto roce [online]. Ekcr.cz [quoted on 29. 1. 2017]. Available at <http://ekcr.cz/1/aktuality-promedia/2208-odchody-exekutoru-pokracuji-minuly-tyden-rezignoval-jiz-11-exekutor-v-tomto-roce?w=>

Opinion of the Civil Law and Commercial Collegium of the Supreme Court of 15. 2. 2006, Cpjn 200/2005, published under No. 31/2006 Collection of Court Decisions and Opinions.

Opinion of the Constitutional Court of 12. 9. 2006, ref. No. Pl. ÚS - st. 23/06.

PALLER, Miroslav. 20. výročie existencie slovenskej komory exekútorov. Komorní listy, 2016 , vol. 8, No. 4, p.. 76-78.

Parliamentary document 725/0. Draft Bill on Judicial Officers [online]. House of Representatives of the Parliament of the Czech Republic [quoted on 29. 1. 2017]. Available at $<$ http://www.psp.cz/sqw/text/tiskt.sqw? $=3 \& c t=725 \& c t 1=0>$.

Podkonický zvolen do Výboru Mezinárodní unie soudních exekutorů [online]. vz24.cz, 10. 5. 2012 [quoted on 29.1.2017]. Available at <http://www.vz24.cz/clanky/podkonicky-zvolen-do-vyboru-mezinarodni-unie-soudnich-exekutoru/>.

Regulations of the Ministry of Justice of the Slovak Republic No. 288/1995 Coll., on Remuneration and Compensations for Judicial Officers. 
SAHULA, David. Dramaticky roste počet dlužníků s více exekucemi. Čtyři a více exekucí již má 380 tisíc lidí [online]. Právní prostor, 8. 10. 2015 [quoted on 29. 1. 2017]. Available at <http://www.pravniprostor.cz/aktuality/aktuality/dramaticky-roste-pocet-dluzniku-s-vice-exekucemi-ctyri-a-vice-exekuci-jiz-ma-380-tisic-lidi>.

SICKLINGER, Stephan. Das neue tschechische Insolvenzrecht aus der Sicht des deutschen Gläubigers. Sipplingen: JWV Jenaer Wissenschaftliche Verlagsgesellschaft mbH, 2009, p. 27.

ŠEDIVÝ, Jiří. Čeští exekutoři nikterak nevyčnívají [online]. Peníze.cz [quoted on 29. 1. 2017]. Available at <http://www.penize.cz/17493-cesti-exekutori-nikterak-nevycnivaji>.

Supreme Court judgement of 23. 10. 2014, Ref. No. 21 Cdo 3182/2014, published under No. 32/2015 Collections judgments and opinions.

Territorial jurisdiction of judicial officers applies throughout the whole European Union [online]. Platforma za teritorialitu soudních exekutorů, 19. 11. 2014 [quoted on 31. 1. 2016]. Available at $<$ http://teritorialita.webnode.cz/news/mistni-prislusnost-soudnich-exekutoru-funguje-v-cele-evropske-unii/>.

The Judicial Officer in the World - Belgium [online]. Uihj.cz, 10. 11.2015 [quoted on 29. 1. 2017]. Available at $<$ http://www.uihj.com/en/ressources/21650/87/belgium_-en.pdf $>$.

The Judicial Officer in the World - France [online]. Uihj.cz, 10. 11.2015 [quoted on 29. 1. 2017]. Available at <http://www.uihj.com/en/ressources/10148/54/france_-_en.pdf >.

The Judicial Officer in the World - Germany [online]. Uihj.cz, 10. 11.2015 [quoted on 29. 1. 2017]. Available at <http://www.uihj.com/en/ressources/21650/84/germany_-_ en.pdf >.

The Judicial Officer in the World - Hungary [online]. Uihj.cz, 10. 11.2015 [quoted on 29. 1. 2017]. Available at $<$ http://www.uihj.com/en/ressources/10148/50/hungary_-en.pdf $>$.

The Judicial Officer in the World - Netherlands [online]. Uihj.cz, 10. 11.2015 [quoted on 29. 1. 2017]. Available at <http://www.uihj.com/en/ressources/10148/86/netherlands_-_en.pdf>.

The Judicial Officer in the World - Slovakia [online]. Uihj.cz, 10. 11.2015 [quoted on 29. 1. 2017]. Available at <http://www.uihj.com/en/ressources/10148/78/slovakia_-_ en.pdf $>$.

UITDEHAAG, Jop. Budoucnost soudního exekutora. . Komorní listy, 2016, vol. 8, No. 4, p. $43-46$.

Vymáhání pohledávek v Rakousku [online]. Business info, 18. 11. 2011 [cit. 29. 1. 2017]. Dostupné na <http://www.businessinfo.cz/cs/clanky/vymahani-pohledavek-v-rakousku-372.html>.

Závěrečná analýza systémových chyb na poli exekucí [online]. Iuridicum Remedium, o. s., 2012 [quoted on 29. 1. 2017]. Available at <http://www.osf.cz/wp-content/ uploads/2015/08/IuRe_Zaverecna_analyza_systemovych_chyb_na_polic_exekuci_ cervenec_2012.pdf>. 